\title{
Design and Design Thinking in STEM Education
}

\section{Yeping $\mathrm{Li}^{1}$ • Alan H. Schoenfeld ${ }^{2} \cdot$ Andrea A. diSessa $^{2} \cdot$ Arthur C. Graesser $^{3}$. Lisa C. Benson ${ }^{4} \cdot$ Lyn D. English ${ }^{5} \cdot$ Richard A. Duschl ${ }^{6}$}

Published online: 30 October 2019

(C) Springer Nature Switzerland AG 2019

\begin{abstract}
Design and design thinking are vital to creativity and innovation, and have become increasingly important in the current movement of developing and implementing integrated STEM education. In this editorial, we build on existing research on design and design thinking, and discuss how students' learning and design thinking can be developed through design activities in not only engineering and technology, but also other disciplines as well as integrated STEM education.
\end{abstract}

Keywords Design $\cdot$ Design thinking $\cdot$ Models of thinking $\cdot$ STEM education $\cdot$ STEM integration

\section{Introduction}

In our first joint editorial ( $\mathrm{Li}$ et al. 2019), we focused on the topic of thinking and uncovered new questions through a brief review of conceptions of thinking, how they

\author{
Yeping Li \\ yepingli@tamu.edu \\ Alan H. Schoenfeld \\ alans@berkeley.edu \\ Andrea A. diSessa \\ disessa@berkeley.edu \\ Arthur C. Graesser \\ graesser@memphis.edu \\ Lisa C. Benson \\ lbenson@clemson.edu \\ Lyn D. English \\ l.english@qut.edu.au \\ Richard A. Duschl \\ rduschl@smu.edu
}

Extended author information available on the last page of the article 
were developed, and related research. We also proposed that thinking needs to be reconceptualized as plural, in contrast to traditional conception of thinking as a single individual-based cognitive process. Specifically, we indicated that thinking can be differentiated as multiple models with levels, and science, technology, engineering, and mathematics (STEM) education is positioned to develop students' thinking with our newly proposed conception. In this editorial, we would like to extend the previous discussion to focus on design and design thinking, and take the position of viewing design thinking as a model of thinking that is important for every student to develop and have in the twenty-first century. Furthermore, we discuss ways that STEM education is positioned to provide diverse opportunities to facilitate students' learning through design and develop their design thinking.

In the following sections, we start by discussing the conceptions of design and design thinking in general, followed by discussion of developing students' design thinking, as a model of thinking, through design activities not only in technology and engineering, but also design activities and content learning in science and mathematics as well as integrated STEM education.

\section{Everyone Designs and can Design}

Design, if referring to formal and professional activity, becomes a term that is often reserved for some professionals, such as those in architecture, fashion, technology, and engineering. The identity development of professional designers and engineers builds on special training and years of practices, with their design activities often leading to valuable end-products. Clearly, design is not a type of activity that is commonly used in school education, except in art and vocational training, as many traditional school subjects like mathematics and science aren't viewed as disciplines in which students design. The well-established knowledge structures and procedures in mathematics and science have long been perceived as important for students to acquire and use as (often disconnected and static) facts, procedures and skills (Banilower et al. 2013; Fisher 1990). Not surprisingly, design activity and design thinking have not been emphasized in traditional school education as they can be easily perceived as creating new terms and procedures, activities often viewed as belonging to professional mathematicians and scientists, not students.

In contrast, engineering and technology are the professional fields that take design as an important and distinguishing activity (e.g., Daly et al. 2012; Haupt 2018; Simon 1996). It is common and important for novices and experts alike to learn and think about design in the fields of engineering and technology, and to develop a design mindset. Thus, the recent introduction of engineering and technology in school education brings new perspectives about what students can and should learn and do, including design, and benefits students can realize from design activity, including the development of design thinking (ITEA 2007; National Research Council 2009). As design and design thinking also encourage different perspectives and approaches in viewing and solving problems, they are vital to creativity and innovation. The importance of design and design thinking has indeed been recognized in school education recently, especially in the current movement of STEM education (e.g., Honey et al. 2014; ITEA 2007; Katehi et al. 2009; NGSS Lead States 2013). 
The above contrast in what students can be expected to learn and develop across different subjects suggests a subject fixation long in existence in school education. It is not because design and design thinking are not important for students to do and develop especially in the twenty-first century, but likely due to the fact that mathematics and science have historically been perceived as not the 'right' type of school subjects in which students design and develop design thinking. The development of students' design thinking is thus left to those teachers of certain subjects such as engineering or art, but not for others in traditional school subjects like mathematics and science (Li et al. 2019). Such a perception needs to be changed!

If not restricted the meaning of design to formal activity in specific professional fields, design can take place in many different ways from time to time. In fact, we all carry out informal and formal designs in our daily and academic lives such as in travel planning, house decorations, hair styling, experimental design in research, and instructional design in school education. Design can simply mean a person's approach to identifying and solving a problem in this human-made world. According to Cunningham, founder and director of "Engineering is Elementary" (EiE, http://www.eie.org), children are born engineers, and they have innate enthusiasm toward designing and making their creations, taking things apart, and figuring out how things work (Cunningham 2009). In fact, one important category of EiE curriculum design principles is to demonstrate that everyone engineers and everyone can engineer (Cunningham and Lachapelle 2016). Consistently, we believe that everyone designs and everyone can design. Without close attention to children's design ideas and intuition, we may lose opportunities to nurture their design thinking and creativity. It is imperative that school curricula and instruction integrate design in students' subject content learning, not just in engineering and technology but also in other STEM subjects and beyond, and also help foster their design intuition and thinking early on (e.g., Center for Childhood Creativity 2018; Early Childhood STEM Working Group 2017).

\section{Design Thinking as a Model of Thinking that is Important to Every Student}

Studies on design and design thinking are not new, especially in engineering (e.g., Dym et al. 2005; Simon 1973, 1996). However, the meanings of design and design thinking are still open to different interpretations in different professional fields (Exter et al. 2019; JohanssonSköldberg et al. 2013; Kolko 2018; Wrigley and Straker 2015). As examples, design in business management often means deliberated and careful thinking and planning to be creative and innovative, but design in engineering can sometimes be routine and taken for granted (Johansson-Sköldberg et al. 2013). In education settings, design research calls for theory-based interventions that can produce results pertinent and documentable to a specific real context (Brown 1992; Cobb et al. 2003). The ambiguity over the meanings of design and design thinking itself historically has also contributed to the difficulty of operationalizing design concept for curriculum and instruction, even in the field of engineering (e.g., Dym et al. 2005). For example, engineering education in universities has evolved from being largely on an "engineering science" model as influenced by Simon's work (1996), to being reflective practices often characterized by project-based learning (PBL) and cornerstone courses (Dym et al. 2005; Schön 1983). 
To study and characterize design thinking in engineering and other fields, various approaches and perspectives have been developed and used, including (1) modeling design process (e.g., Dym and Brown 2012; Schön 1983; Simon 1996), (2) comparing experts and novices (e.g., Ahmed et al. 2003; Göker 1997; Kavakli and Gero 2002; Tang and Gero 2001), (3) identifying and specifying design thinking strategies, tactics and skills (e.g., Lawson 2006; Wendell et al. 2017), (4) examining specific cognitive features, such as cognitive load (e.g., Sweller et al. 2019) and metacognition (Desoete and Özsoy 2009; Kavousi et al. 2019; McLaren and Stables 2008), and (5) examining action and thinking in design teams (Hu et al. 2018; McNeill et al. 1998; Stempfle and Badke-Schaube 2002). Previous studies on design thinking have been fruitful, and also diverse in terms of different aspects or dimensions being focused on. For example, Razzouk and Shute's review (2012) suggested that experts in design demonstrated performance different from novices in multiple ways, including efficiency and effectiveness based on their prior experience, metacognitive control, and the tendency of starting with solution assumptions rather than problem analysis. Such results help us develop a better understanding about not only the nature of expertise in design, but also possible ways of specifying levels of design thinking.

In their study of expert-novice architects in designing a museum building, Tang and Gero (2001) used a coding scheme that consists four levels: (a) the physical level, which refers to the instances that have direct relevance to the external world, comprising drawing, looking and moving actions; (b) the perceptual level, concerns the instances of attending to visual-spatial features/relationships in an automatic perceptual mechanism; (c) the functional level, relates to the instances of functional references mapped between visual-spatial features/relationships and abstract concepts, including meanings and functions; and (d) the conceptual level, which represents the instances that process abstract concepts and the instances that process physical and perceptual actions. According to Tang and Gero (2001), this four-level scheme was initially developed by Suwa and Tversky (1997) in their study of novice-expert architects' design sketches. It can be classified into two distinguishable groups of actions: (1) lower level cognitive actions that reside at the physical and perceptual levels and refer to interaction with the external world, including actions for drawing, looking, and recognizing graphical features and spatial relationships; (2) higher level cognitive actions that stay at the functional and conceptual levels and refer to interactions with the designer's internal world, including actions for functional reference, goalsetting, making decisions, and utilizing designers' knowledge. Their study showed that while both the novice and expert produced large amounts of drawing, looking, moving, and perceiving actions with functional meaning attached to them, the expert produced statistically significant more of these actions than the novice.

The four-level scheme used in Tang and Gero's study (2001) is mainly a coding framework for data analyses. Their results also show that both the novice and the expert demonstrated actions in all four levels, and their documented differences were mainly in terms of quantity, not quality. Although such a scheme may not be ready for use to characterize the level of development in design thinking, for example, from a novice to an expert designer, it suggests aspects that we can consider when thinking about students' design thinking development. This is a topic area that would need more theoretical, empirical, and educational research. 
School education differs from professional education in terms of emphasizing identity development in different professional fields such as architecture, fashion, and engineering. In school education, design has been increasingly recognized not only as an object for students to learn and experience (e.g., English 2018; McFadden and Roehrig 2019), but also a general framework for school education (e.g., Wright and Wrigley 2019) and an important approach for conceptualizing and developing integrated STEM education in K-12 schools (e.g., English 2016; Kelley and Knowles 2016). Likewise, design thinking has been studied not only as a complex and integral part of the design process in engineering (e.g., Dym et al. 2005) and school education (e.g., Strimel et al. 2019), but also as a general cognitive process involving creation, experimentation, feedback collection, and redesign that can take place in many different fields (Razzouk and Shute 2012) including business (e.g., Dunne and Martin 2006) and instructional design (e.g., Cook 2006).

To develop students' design thinking, we need to take a broad perspective about design and design thinking that can capture both formal and informal design activities. Historically, thinking involved in design practices has been explored mainly through examining professional designers' practices. Johansson-Sköldberg et al. (2013) named this type of thinking as "designerly thinking" and summarized related studies and theoretical perspectives into five categories of "design and designerly thinking" (p. 124): the creation of artifacts, a reflexive practice, a problem-solving activity, a way of reasoning/making sense of things, and the creation of meaning. They then reserved the term "design thinking" for the discourse where design practice and competence are used beyond the professional design context (including architecture and art), for and with people without a scholarly background in design, such as in management (p. 123). Design thinking can thus be viewed as a simplified version of "designerly thinking", and is feasible for activities taking place in education, both for and with students. With the goal of identifying the features and characteristics of design thinking in school education, Razzouk and Shute (2012) offered a characterization of design thinking: "Design thinking is generally defined as an analytic and creative process that engages a person in opportunities to experiment, create and prototype models, gather feedback, and redesign.” (p. 330) This characterization provides us a valuable perspective about design thinking that goes beyond possible restrictions placed on design activity by disciplinary boundaries. Further in alignment with our discussion in the first joint editorial ( $\mathrm{Li}$ et al. 2019), design thinking can and should be viewed as a model of thinking in school education to help nurture and develop for every student in the twenty-first century.

Given the relatively new recognition of the importance of design and design thinking in school education, there are many more questions than answers for researchers and educators alike. For example, how to characterize the levels of students' design thinking and related development remains a challenge, particularly for those who care about the design of curriculum and instruction to develop students' design thinking (e.g., Wrigley and Straker 2015). We would certainly view this challenge also as an opportunity for researchers and educators to study and understand the development of design cognition. Educational constructs can be conceptualized and developed in terms of different dimensions, such as the complexity of design tasks and the abstract level of concepts needed in the design process. Experimental studies can then be carried out to examine how different interventions may impact students' development of design thinking (e.g., Dasgupta 2019). 


\section{Develop Students' Design and Design Thinking in and through STEM Education}

How design and design thinking can and should be taught or used has been an issue of importance in different professional fields. Different models have been identified and developed for different purposes including education (e.g., Wright and Wrigley 2019; Wrigley and Straker 2015) and assessment (e.g., Kretzschmar 2003). For example, Wrigley and Straker (2015) proposed an educational design ladder based on a study of what is taught (content) and how it is taught (assessment and learning modes) about design thinking in universities worldwide. Specifically, they collected and reviewed 51 courses about design thinking in different disciplines including business, management, innovation, and creativity, as selected from 28 universities internationally. Their review and analyses of these courses led them to propose the five pedagogical stages in the development of design thinking, ranging from low to high-order thinking skills anticipated for different levels of design thinking. These levels of design thinking are categorized as the foundational level, product level, project level, business level, and professional level. They further characterize these five levels of design thinking development in the cumulative nature of learning with Biggs' Structure of the Observed Learning Outcome (SOLO) taxonomy (1996): (1) knowledge comprehension, (2) application, (3) analysis, (4) synthesis, and (5) evaluation. Given that the model is derived from reviewing professional courses about design thinking in universities, it is thus understandable that the depiction of different levels of design thinking tends to illustrate how a professional in design may be prepared through the ladder.

\section{Students' Learning through (Engineering) Design in STEM Education}

In school education, existing studies have shown that students can learn through design and also develop their design thinking in and through STEM education. Specifically, with the recent introduction of engineering into school education, there are a fast growing set of programs and studies that document how engineering design can help engage students and facilitate their learning of STEM content (e.g., Engineering is Elementary (EiE). 2011; English and King 2015; Kelley and Sung 2017; Kelly and Cunningham 2019; McFadden and Roehrig 2019; Schnittka 2012; Strimel et al. 2018) and thinking development (e.g., Lubinski 2010; Uttal and Cohen 2012). For example, Kelley and Sung (2017) investigated how the use of engineering design helped grade 5 students to learn science. They found that student participants increased the amount of time spent on computational thinking by $34 \%$ when given a math-embedded design task. Pre- and post-tests showed that students gained significant science content knowledge, such as identifying the concept of conservation of mass on a multiplechoice test. At the same time, however, most of the students struggled to transfer it to a new situation. The acquisition of basic knowledge and practices in STEM is certainly not enough. Kelley and Sung (2017) thus concluded that elementary science teachers using engineering design as an approach to improve science learning also need to provide additional opportunities for students to improve their ability to transfer science and mathematical reasoning beyond the initial design tasks.

Kelly and Cunningham (2019) examined how engineering design provides unique ways to support students' collaborative sense-making, reasoning with evidence, and 
assessing knowledge. They drew from EiE engineering curricular units and their implementation to identify epistemic tools, including the physical, symbolic, or discursive artifacts that facilitate knowledge construction, that helped facilitate students in three epistemic practices of engineering (1) constructing models and prototypes, (2) making trade-offs between criteria and constraints for engineering design challenges, and (3) communicating through uses of conventionalized verbal, written, and symbolic modes of disciplinary discourses. Their analysis of curriculum products, student work, and classroom discourse demonstrated how the use of these epistemic tools is important for engaging students in these epistemic practices, and also helps foster creating, sharing, and assessing knowledge claims. The results obtained by Kelly and Cunningham (2019) highlighted the importance of specific epistemic tools identified and used in engineering practices for K-12 education, and provide a ground feasible for comparing and connecting with what scientific practices aim to accomplish in knowledge learning and construction through the process (e.g., Duschl and Bybee 2014). It presents an important topic area for us to further identify, examine, and compare specific epistemic practices pertinent to different disciplines in STEM that can possibly be connected or integrated to facilitate students' content learning and thinking development. Moreover, as STEM education is not culturally neutral (Early Childhood STEM Working Group 2017), how culture plays a role in design activity and different epistemic practices is also an important topic for improving students' learning in STEM and their design thinking in a diverse classroom and across regions.

Rather than focusing on the use of engineering design, some researchers and educators tried to develop and use design as a general pedagogical approach to engage students and help them learn in STEM and STEAM (with art specifically included in STEM) (e.g., Chen and Lo 2019; English 2018; Orona et al. 2017). As part of a 4-year longitudinal study, English (2018) reported a 4th-grade classroom design-based problem solving activity that integrated the four STEM disciplines. With a focus on a shoe design task, students built upon their learning from an initial problem component that collected and analyzed data about shoe types, sizes, fabrics, corresponding foot lengths etc., and obtained further knowledge about natural and processed materials from the science curriculum and general information about shoe designers, manufacturers and their work. Students were then organized into small groups to design their own shoes. The process and results illustrated how student learning progressed from knowledge application and the use of a sequence of design strategies as beginning designers, redesigning, reconstructing, to informed designing. The process, guided by a conceptual framework adapted from Crismond and Adams (2012), was similar to the educational design ladder described above by Wrigley and Straker (2015). Along the process of design development, English also reported that students not only became more aware of the STEM knowledge they were using or needed to use, but also were able to make knowledge-based decisions and explanations. Different from the "progressivism" of immersion learning that was criticized by Gee (2005), design activity in these studies is structured and used with specific purposes and appropriate instructional support. The positive effects of design activities in STEM clearly require careful instructional designs with specific theoretical perspectives. Further efforts are needed to explore both specific mechanisms and pedagogical constructs for developing and using design activity to facilitate students' content learning and thinking development. 


\section{Students' Design Practices Benefited from Integrated STEM Education}

Recent research suggested that the benefits of design in STEM education goes both ways: there are mutual benefits for design and integrated STEM education. In addition to what is discussed above that design can help students learn and develop design thinking, integrated STEM education can also benefit students in design practices (e.g., English 2018; Fan and Yu 2017).

Specifically, Fan and Yu (2017) conducted a quasi-experimental study that compared high school students' learning outcomes between a group studying a STEM engineering module and another group studying a technology education module. While controlling for the content and other aspects of the two modules, they found that after 10 weeks of instruction, the students using the STEM engineering module significantly outperformed the students studying the technology education module in the areas of conceptual knowledge, higher-order thinking skills, and the engineering design project activity. Their further analyses revealed that the key differences in the application of design practice between these two groups included (a) their respective problem prediction and (b) their analysis capabilities. The positive effect of the use of an integrative STEM approach in high school technology education is well illustrated and documented in their study. Likewise, English's study (2018), as discussed above, demonstrated the benefits for student learning in an integrated STEM curriculum and instruction. Although it was not conducted as a quasi-experimental study with a comparison group and different from Fan and Yu's study (2017) that focused on engineering design, English also demonstrated such benefits for students in developing their design practices and design thinking.

\section{Embed the Development of Students' Design Thinking Not Only in Technology and Engineering, But Also in Mathematics and Science}

One point that we would like to emphasize through this editorial is that everyone can design both informally and formally, and not only in engineering and technology but also in mathematics and science (i.e., change the subject fixation perception).

Designs in education research are not unfamiliar to education researchers (Burkhardt and Schoenfeld 2003; Cobb et al. 2003), nor are experimental designs in chemistry, physics and biology unfamiliar to scientists and science educators. We should help our students pay close attention to the design process, idea generation and their thinking, rather than focusing only on readily available facts and procedures.

The same applies to needed changes in viewing, teaching and learning mathematics, a subject that is typically perceived as non-experimental and different from the other STEM fields (e.g., English 2016). There are several ways for making such needed changes. For example, the use of project-based learning (PBL) in the current movement of STEM education can and should also be used in mathematics teaching and learning. Over the past several years, Teaching Children Mathematics, a National Council of Teachers of Mathematics (NCTM) professional publication focusing mainly on elementary mathematics teachers, has established a special section called iSTEM. It publishes examples of investigations, projects, and instructional activities associated with STEM, developed and used by and for teachers. For example, Orona et al. (2017) shared an example of how standard units of measure can be understood and used in the 
context of a design-based problem solving activity. The article started with the introduction of a multi-step engineering design process, then introduced how to apply it to a problem-solving activity in a second-grade mathematics classroom. With their initial learning of standard units of measurement and the engineering design process, students were then challenged to conduct an investigation to create a cutout of a giant's head to match the giant's hand-prints as provided. The students went through the whole process of questioning, brainstorming, planning, constructing, improving, and sharing. Specifically, students were challenged to find out the relationship between hand measurement and body or facial features, by looking at themselves and measuring and drawing. The process built on and expanded their knowledge of the engineering design process and standard units of measurement.

Indeed, design is not unique to engineering and technology. There are many other sources and materials that have been produced and shared to demonstrate the importance and use of design and design thinking in school education. For example, Educational Designer (see https://www.educationaldesigner.org/ed/) is an international free e-journal specifically on design and development in education. It was established in 2008 by the International Society for Design and Development in Education with the goal of promoting excellence in the research-based design, development, and evaluation of educational materials in the fields of mathematics, science, engineering, and technology. With the participation of mathematics educators in this society and journal, readers can find resources related to design in mathematics education in curriculum, instruction, research, and professional development.

\section{Coda}

It becomes clear and important to us, in school education, to take a broad perspective on design and design thinking and not restrict design as only belonging to professional fields such as architecture and engineering. While the introduction of engineering and technology in school education helped us to realize the importance of design and design thinking, it is at least as important for us to rethink how traditional school subjects like mathematics and science can and should be taught and learned. Design is not only a noun, but also a verb that can help bring changes to what school education can offer to our students. There is a rapidly growing number of studies, such as those we discussed above, that document how STEM education is well positioned to provide diverse opportunities to benefit students' learning and design practices.

At the same time, design thinking, as a model of thinking, is important for every student to develop and have in the twenty-first century. Given the fact that previous studies mainly focused on professional designers and engineers' cognition, studies on students' design thinking and its development are still limited. Existing studies have illustrated that this is a rich and fruitful area for scholarly discussion and research (e.g., Kavousi et al. 2019; Strimel et al. 2019; Wind et al. 2019). Systematic studies on students' design thinking and its development, especially in and through STEM education, would help provide important foundations for developing sound educational programs and instruction. This journal encourages submission of related research on design and design thinking in STEM education, a frontier in STEM education research that calls for new and robust scholarship (Li 2018). 


\section{References}

Ahmed, S., Wallace, K. M., \& Blessing, L. T. M. (2003). Understanding the differences between how novice and experienced designers approach design tasks. Research in Engineering Design, 14, 1-11.

Banilower, E. R., Smith, P. S., Weiss, I. R., Malzahn, K. A., Campbell, K. M., et al. (2013). Report of the 2012 national survey of science and mathematics education. Horizon Research, Chapel Hill, NC. Retrieved from http:/www.nnstoy.org/download/stem/2012\%20NSSME\%20Full\%20Report.pdf. Accessed 03 Sept 2019.

Biggs, J. (1996). Enhancing teaching through constructive alignment. Higher Education, 32, 347-364.

Brown, A. L. (1992). Design experiments: Theoretical and methodological challenges in creating complex interventions in classroom settings. Journal of the Learning Sciences, 2(2), 141-178.

Burkhardt, H., \& Schoenfeld, A. H. (2003). Improving educational research: Toward a more useful, more influential, and better funded enterprise. Educational Researcher, 32(9), 3-14.

Center for Childhood Creativity, Bay Area Discovery Museum (2018). The Roots of STEM Success: Changing Early Learning Experiences to Build Lifelong Thinking Skills. Retrieved from https:/centerforchildhoodcreativity.org/wp-content/uploads/sites/2/2018/02/CCC_The_Roots_of_ STEM_Early_Learning.pdf. Accessed 09 Sept 2019.

Chen, C. W. J., \& Lo, K. (2019). From teacher-designer to student-researcher: A study of attitude change regarding creativity in STEAM education by using Makey Makey as platform for human-centered design instrument. Journal for STEM Education Research, 2(1), 75-91.

Cobb, P., Confrey, J., diSessa, A., Lehrer, R., \& Schauble, L. (2003). Design experiments in educational research. Educational Researcher, 32(1), 9-13.

Cook, M. P. (2006). Visual representations in science education: The influence of prior knowledge and cognitive load theory on instructional design principles. Science Education, 90(6), 1073-1091.

Crismond, D. P., \& Adams, R. S. (2012). The informed design teaching and learning matrix. Journal of Engineering Education, 101(4), 738-797.

Cunningham, C. M. (2009). Engineering is elementary. The Bridge, 30(3), 11-17.

Cunningham, C. M., \& Lachapelle, C. P. (2016). Design engineering experiences to engage all students. Educational Designer, 3(9), 1-26.

Daly, S. R., Adams, R. S., \& Bodner, A. M. (2012). What does it mean to design? A qualitative investigation of design professionals' experiences. Journal of Engineering Education, 101, 187-219.

Dasgupta, C. (2019). Improvable models as scaffolds for promoting productive disciplinary engagement in an engineering design activity. Journal of Engineering Education, 108(3), 394 417. https://doi.org/10.1002 /jee.20282.

Desoete, A., \& Özsoy, G. (2009). Introduction: Metacognition, more than the lognes monster. International Electronic Journal of Elementary Education, 2(1), 1-6.

Dunne, D., \& Martin, R. (2006). Design thinking and how it will change management education: An interview and discussion. Academy of Management Learning \& Education, 5, 512-523. https://doi.org/10.5465 /AMLE.2006.23473212.

Duschl, R. A., \& Bybee, R. W. (2014). Planning and carrying out investigations: An entry to learning and to teacher professional development around NGSS science and engineering practices. International Journal of STEM Education, 1, 12. https://doi.org/10.1186/s40594-014-0012-6.

Dym, C. L., \& Brown, D. (2012). Engineering design: Representation and reasoning (2nd ed.). New York: Cambridge University Press.

Dym, C. L., Agogino, A. M., Eris, O., Frey, D. D., \& Leifer, L. J. (2005). Engineering design thinking, teaching, and learning. Journal of Engineering Education, 94(1), 103-120.

Early Childhood STEM Working Group, University of Chicago STEM Education \& Erikson Institute (2017). Early STEM Matters: Providing high-quality STEM Experience for All Young Learners. Retrieved from https://d3lwefg3pyezlb.cloudfront.net/docs/Early_STEM_Matters_FINAL.pdf. Accessed 09 Sept 2019.

Engineering is Elementary (EiE). (2011). Engineering curriculum for grades 1-5. Boston: Museum of Science http://www.eie.org/eie-curriculum. Accessed 19 Aug 2019.

English, L. D. (2016). STEM education K-12: Perspectives on integration. International Journal of STEM Education, 3, 3. https://doi.org/10.1186/s40594-016-0036-1.

English, L. D. (2018). Learning while designing in a fourth-grade integrated STEM problem. International Journal of Technology and Design Education. https://doi.org/10.1007/s10798-018-9482-z.

English, L. D., \& King, D. T. (2015). STEM learning through engineering design: Fourth-grade students' investigations in aerospace. International Journal of STEM Education, 2, 14. https://doi.org/10.1186 /s40594-015-0027-7. 
Exter, M. E., Gray, C. M., \& Fernandez, T. M. (2019). Conceptions of design by transdisciplinary educators: Disciplinary background and pedagogical engagement. International Journal of Technology and Design Education. https://doi.org/10.1007/s10798-019-09520-w.

Fan, S., \& Yu, K. (2017). How an integrative STEM curriculum can benefit students in engineering design practices. International Journal of Technology and Design Education, 27, 107-129.

Fisher, C. (1990). The Research Agenda Project as prologue. Journal for Research in Mathematics Education, 21, 81-89.

Gee, J. P. (2005). What would a state of the art instructional video game look like? Innovate: Journal of Online Education, 1(6) Retrieved from https://nsuworks.nova.edu/innovate/vol1/iss6/1. Accessed 03 Sept 2019.

Göker, M. H. (1997). The effects of experience during design problem solving. Design Studies, 18, 405-426. https://doi.org/10.1016/S0142-694X(97)00009-4.

Haupt, G. (2018). Design in technology education: Current state of affairs. In M. J. de Vries (Ed.), Handbook of technology education (pp. 643-659). Berlin: Springer.

Honey, M., Pearson, G., \& Schweingruber, H. (Eds.). (2014). STEM integration in K-12 education: Status, prospects, and an agenda for research. Washington, DC: National Academies Press.

Hu, Y., Du, X., Bryan-Kinns, N., \& Guo, Y. (2018). Identifying divergent design thinking through the observable behavior of service design novices. International Journal of Technology and Design Education. https://doi.org/10.1007/s10798-018-9479-7.

International Technology Education Association (ITEA). (2007). Standards for technological literacy: Content for the study of technology. Reston: Author.

Johansson-Sköldberg, U., Woodilla, J., \& Çetinkaya, M. (2013). Design thinking: Past, present and possible futures. Creativity and Innovation Management, 22, 121-146.

Katehi, L., Pearson, G., \& Feder, M. (Eds.) (2009). Engineering in K-12 education: Understanding the status and improving the prospects. Committee on K-12 engineering education, National Academy of Engineering and National Research Council. Washington, DC: The National Academies Press.

Kavakli, M., \& Gero, J. (2002). The structure of concurrent cognitive actions: A case study on novice and expert designers. Design Studies, 23, 25-40. https://doi.org/10.1016/S0142-694X(01)00021-7.

Kavousi, S., Miller, P. A., \& Alexander, P. A. (2019). Modeling metacognition in design thinking and design making. International Journal of Technology and Design Education. https://oi.org/10.1007/s10798-019-09521-9.

Kelley, T. R., \& Knowles, J. G. (2016). A conceptual framework for integrated STEM education. International Journal of STEM Education, 3, 11. https://doi.org/10.1186/s40594-016-0046-z.

Kelley, T. R., \& Sung, E. (2017). Examining elementary school students' transfer of learning through engineering design using think-aloud protocol analysis. Journal of Technology Education, 28(2), 83-108.

Kelly, G. J., \& Cunningham, C. M. (2019). Epistemic tools in engineering design for K-12 education. Science Education, 103, 1080-1111.

Kolko, J. (2018). The divisiveness of design thinking. Interactions, 25(3), 28-34. https://doi.org/10.1145 /3194313.

Kretzschmar, A. (2003). The economic effects of design. Danish National Agency for Enterprise and Housing. Retrieved from https://pdfs.semanticscholar.org/754f/a0095d0c7ec4cb1c0c0b4cd1a95cc5b1050b.pdf? ga=2.15505206.1234127766.1567435060-917139965.1534510346. Accessed 03 Sept 2019.

Lawson, B. (2006). How designers think - The design process demystified. Boston: Elsevier.

Li, Y. (2018). Journal for STEM education research - Promoting the development of interdisciplinary research in STEM education. Journal for STEM Education Research, 1(1-2), 1-6. https://doi.org/10.1007/s41979018-0009-z.

Li, Y., Schoenfeld, A. H., diSessa, A. A., Graesser, A. C., Benson, L. C., English, L. D., \& Duschl, R. A. (2019). On thinking and STEM education. Journal for STEM Education Research, 2(1), 1-13. https://doi. org/10.1007/s41979-019-00014-x.

Lubinski, D. (2010). Spatial ability and STEM: A sleeping giant for talent identification and development. Personality and Individual Differences, 49(4), 344-351.

McFadden, J., \& Roehrig, G. (2019). Engineering design in the elementary science classroom: Supporting student discourse during an engineering design challenge. International Journal of Technology and Design Education, 29, 231-262.

McLaren, S., \& Stables, K. (2008). Exploring key discriminators of progression: Relationships between attitude, meta-cognition and performance of novice designers at a time of transition. Design Studies, 29(2), 181-201.

McNeill, T., Gero, J., \& Warren, J. (1998). Understanding conceptual electronic design using protocol analysis. Research in Engineering Design, 10, 129-140. https://doi.org/10.1007/BF01607155.

National Research Council. (2009). Engineering in K-12 education: Understanding the status and improving the prospects. Washington, DC: National Academies Press. 
NGSS Lead States. (2013). Next generation science standards: For states, by states. Washington, DC: National Academies Press.

Orona, C., Carter, V., \& Kindall, H. (2017). Understanding standard units of measure. Teaching Children Mathematics, 23(8), 500-503.

Razzouk, R., \& Shute, V. (2012). What is design thinking and why is it important? Review of Educational Research, 82(3), 330-348.

Schnittka, C. G. (2012). Engineering education in the science classroom: A case study of one teacher's disparate approach with ability-tracked classrooms. Journal of Pre-College Engineering Education Research (J-PEER), 2(1), Article 5. https://doi.org/10.5703/1288284314654.

Schön, D. A. (1983). The reflective practitioner. London: Temple-Smith.

Simon, H. A. (1973). The structure of ill structured problems. Artificial Intelligence, 4, 181-201. https://doi. org/10.1016/0004-3702(73)90011-8.

Simon, H. A. (1996). The sciences of the artificial (3rd ed.). Cambridge: MIT Press.

Stempfle, J., \& Badke-Schaube, P. (2002). Thinking in design teams-An analysis of team communication. Design Studies, 23, 473-496. https://doi.org/10.1016/S0142-694X(02)00004-2.

Strimel, G. J., Bartholomew, S. R., Kim, E., \& Zhang, L. (2018). An investigation of engineering design cognition and achievement in primary school. Journal for STEM Education Research, 1(1-2), 173-201.

Strimel, G. J., Kim, E., Grubbs, M. E., \& Huffman, T. J. (2019). A meta-synthesis of primary and secondary student design cognition research. International Journal of Technology and Design Education. https://oi. org/10.1007/s10798-019-09505-9.

Suwa, M., \& Tversky, B. (1997). What do architects and students perceive in their design sketches? A protocol analysis. Design Studies, 18, 385-403.

Sweller, J., van Merriënboer, J. J. G., \& Paas, F. (2019). Cognitive architecture and instructional design: 20 years later. Educational Psychology Review, 31, 261-292.

Tang, H.-H., \& Gero, J. S. (2001). Sketches as affordances of meanings in the design process. In J. S. Gero, B. Tversky, \& T. Purcell (Eds.), Visual and spatial reasoning in design II (pp. 271-282). Sydney: University of Sydney, Australia: Key Center of Design Computing and Cognition.

Uttal, D. H., \& Cohen, C. A. (2012). Spatial thinking and STEM education: When, why, and how? Psychology of Learning and Motivation, 57, 147-181.

Wendell, K. B., Wright, C. G., \& Paugh, P. (2017). Reflective decision-making in elementary students' engineering design. Journal of Engineering Education, 106(3), 356-397. https://doi.org/10.1002 /jee.20173.

Wind, S. A., Alemdar, M., Lingle, J. A., Moore, R., \& Asilkalkan, A. (2019). Exploring student understanding of the engineering design process using distractor analysis. International Journal of STEM Education, 6 , 4. https://doi.org/10.1186/s40594-018-0156-x.

Wright, N., \& Wrigley, C. (2019). Broadening design-led education horizons: Conceptual insights and future research directions. International Journal of Technology and Design Education, 29, 1-23.

Wrigley, C., \& Straker, K. (2015). Design thinking pedagogy: The educational design ladder. Innovations in Education and Teaching International. https://doi.org/10.1080/14703297.2015.1108214.

Publisher's Note Springer Nature remains neutral with regard to jurisdictional claims in published maps and institutional affiliations.

\section{Affiliations}

\section{Yeping $\mathrm{Li}^{1}$ • Alan H. Schoenfeld ${ }^{2}$ - Andrea A. diSessa ${ }^{2}$ - Arthur C. Graesser ${ }^{3} \cdot$ Lisa C. Benson ${ }^{4} \cdot$ Lyn D. English ${ }^{5} \cdot$ Richard A. Duschl ${ }^{6}$}

1 Texas A\&M University, College Station, TX, USA

2 University of California-Berkeley, Berkeley, CA, USA

3 University of Memphis, Memphis, TN, USA

4 Clemson University, Clemson, SC, USA

5 Queensland University of Technology, Brisbane, Australia

6 Southern Methodist University, Dallas, TX, USA 